\title{
In memoriam Hans Küng (1928-2021)
}

\author{
MÅRTEN BJÖRK
}

Den 6 april i år gick den schweiziske teologen Hans Küng bort, 93 år gammal. Född 1928 i Sursee i en välbärgad, romersk-katolsk familj drömde den unge pojken tidigt om att bli präst. Han vigdes vid 26 års ålder och blev professor i Tübingen när han var 32, där han säkerställde att hans vän och senare trätobroder Joseph Ratzinger skulle få en tjänst.

Küng studerade vid Gregoriana i Rom och försvarade 1957 sin avhandling om Karl Barths rättfärdiggörelselära som blev avgörande för den ekumeniska dialogen.

Karl Barth (I886-I968) skrev ett entusiastiskt brev till den unge katoliken och underströk att han inte bara sammanfattat Barths lära på ett uttömmande sätt utan också blottlagt överensstämmelser med den romerskkatolska synen på frågan om handlingar och tro. Hoppas nu bara, skrev den reformerte teologen, att folk inte kommer anklaga mig för att vara kryptokatolik och dig för att vara krypto-protestant.

Ett protesterande, reformerande om inte revolterande drag fanns obestridligen hos Küng, vilken präglades av den anda inom den romerskkatolska kyrkan som efter andra världskriget sökte en teologi för en kyrka som "om vi ska vara ärliga mot oss själva [...] varken är helig eller katolsk". Dessa ord, som Ratzinger yppade under en kurs som Küng tilldelat honom i Tübingen, hade lika gärna kunnat vara den schweiziske teologens.

Kyrkan var emellertid för Küng både helig och allmän. Men den var inte ofelbar - eller snarare, den var ofelbar som gemenskap tillhörig Kristus. Den var inte, enligt honom, ofelbar i den mening som Första Vatikankonciliets ofelbarhetsdogm innebar.

Om Ratzinger under 1950-talet hade sökt sig tillbaka till den franciskansk-augustinska traditionen för att finna ett alternativ till vad han beskrev 
som Optatus av Milevis (d. ca 40o) statskyrkoideal, sökte Küng också nya vägar i den romersk-katolska traditionens långa och inte sällan konfliktfyllda historia.

Stilig, intelligent, kunnig i flera moderna språk och bevandrad i många antika, rättfram och modig, var han älskad av många. Men teologer runtom honom bekymrade sig tidigt över hans humör och, vad man menade, hetsiga läggning.

Küng omfamnade ett element som är axiomatisk i en gemenskap som säger sig bygga på omvändelse och lovar "en ny himmel och en ny jord", nämligen förändring, och 1960 publicerades hans skrift Konzil und Wiedervereinigung, ${ }^{1}$ vilken i någon mån lade kursen för hans teologiska gärning. Kyrkan är en förnyande kraft eller ingenting.

Präglad av Barths kristologiska teologi betonade Küng att förnyelsen inte är en mänsklig angelägenhet utan ett krav som kommer från "Jesus Kristus själv, kyrkans Herre, som, i alla sekel genom sitt evangelium, talar till och kräver saker av henne [kyrkan]". ${ }^{2}$ Detta är det nya: omvändelse av människorna, förnyelse av tingen, genom trohet.

Trohet till Jesus kräver trohet till den kyrka som förmedlar Jesu budskap och denna kyrka var, för Küng, först och främst den romersk-katolska kyrkan. Men frågan är fortfarande vad en sådan trohet innebär. Vid denna tidpunkt var Franciskus av Assisi (ca II8I-I226) idealet för någon som förnyar kyrkan, medan Martin Luther (I483-I546) var någon som bröt med den. Men, betonade Küng, trots detta brott finns det redan gemenskap koinonia - mellan de olika kyrkorna genom dopet, den gemensamma tron och den kärlek som de kristna kyrkorna säger sig representera.

Inte bara de prostituerade och publikanerna var indragna i frälsninsgemenskapen utan också de sinsemellan stridande kyrkorna.

Kyrkans läroämbete var ännu inte ifrågasatt och i de två böcker som Küng skrev under Andra Vatikankonciliet, Strukturen der Kirche och Kirche im Konzil, fortsatte undersökningen som påbörjats med diskussionen om ecklesiologisk enhet och teologisk förnyelse. ${ }^{3}$ Böcker som mottogs mycket positivt bland teologer och historiker.

Den framstående spanske teologen och Augustinuskännaren Argimiro Turrado (1926-2002) avslutade exempelvis en lång recension av Strukturen der Kirche med följande entusiastiska ord: "Hela verket lyser av objektivitet och ödmjukhet [Toda la obra brilla por su objetividad y humildad], värdigt

\footnotetext{
I. Hans Küng, Konzil und Wiedervereinigung: Erneuerung als Rufin die Einheit, Freiburg 1960.

2. Küng, Konzil und Wiedervereinigung, 74.

3. Hans Küng, Strukturen der Kirche, Freiburg 1962; Hans Küng, Kirche im Konzil, Freiburg 1963.
} 
dem som försöker finna lösningar på bestridda och svåra problem, vilka i dag mer än någonsin behöver ett definitivt klargörande från det heliga läroämbetet [Sagrado Magisterio].” En av dessa frågor, betonar Turrado, är frågan om ofelbarhetens gränser och, som de flesta som läser denna text vet, var det denna konflikt som skulle leda till att Küng förvisso inte blev en ny Luther men väl hamnade i konflikt med läroämbetet.

Efter konciliet fortsatte Küng sitt arbete med ecklesiologiska frågor och skrev en rad verk där Die Kirche från 1967 särskilt förtjänar att uppmärksammas. ${ }^{4}$ Detta försök att beskriva kyrkans liv utifrån kategorier som Guds folk (Gottes Volk), andeskapelse (Geistgeschöpf) och Kristi kropp (Christleib) samt utifrån dimensioner som enhet, helighet, katolicitet och apostolicitet, fångar en viktig nerv i Küngs verk. Den sökta enheten gäller emellertid inte blott kyrkans inre liv, utan är en soteriologisk gåva som måste slösas på den omgivande världen så att den förändras och enas. Här kan man ana att om kyrkan inte lyckas åstadkomma den fred som den söker extra muros kommer den inte att kunna producera någon endräkt intra muros.

Gränserna mellan det egna och det främmande är för en soteriologisk gemenskap som väntar på något kommande således i ständig omförhandling. Kyrkans uppgift är att inbegripa det som är i den förnyelse och omvändelse som de bibliska texterna vittnat om sedan Abrams uttåg från Ur.

Men samtidigt, som Küng betonade redan i Konzil und Wiedervereinigung, behöver denna pilgrimsvandring vägvisare och teckentydare och här har kyrkan och även läroämbetet sin givna roll. Frågan uppstår emellertid: vad händer när den kristna gemenskapen pekar åt fel håll? Så som exempelvis skedde i Tyskland under nazi-regimen, vilket det tyska romersk-katolska biskopsmötet nyligen underströk i en 23-sidig skrivelse, eller som med encyklikan Humanae vitae enligt Küng i sin kanske mest omskrivna bok, Unfehlbar? från 1970.5

Küng argumenterade nu för att påvens ofelbarhet inte kan accepteras som en dogm. Boken blev något av en bestseller och såldes, bara i Tyskland, i tiotusentals exemplar. På den romersk-katolska sidan provocerades många, medan en reformert teolog som Willem Visser 't Hooft (I900-1985) sade att att han hade "en atombomb i sina händer. För om dessa idéer accepteras av katoliker kommer en helt ny situation uppstå. Då skulle protestantismen inte ha någon verkligen mening med sin protest".

Även Küngs romersk-katolska allierade, som Karl Rahner (1904-1984), Walter Kasper och Karl Lehmann (I936-20I8), reagerade negativt på boken men uppmanade de tyska biskoparna att inte fördöma den.

4. Hans Küng, Die Kirche, Freiburg 1967.

5. Hans Küng, Unfehlbar? Eine Anfrage, Zürich 1970. 
Küng hävdade för sin del med emfas att han "är och fortsätter trots all kritik att vara en övertygad katolsk teolog”, men i en flersidig intervju i Der Spiegel uttryckte Rahner frustration över sin yngre kollega och sade att "Küng hävdar att det är möjligt [rechnet mit der Möglichkeit] att en påve gör ett misstag även med 'ex-cathedra'-definitioner. Därmed överger Küng, enligt min mening, den inomkatolska teologiska traditionen, då dess förutsättning [...] är att det finns odiskutabla gemensamma åsikter”. ${ }^{6}$

Küngs svar på denna kritik var att han utan att tveka accepterar att det finns odiskutabla gemensamma åsikter som möjliggör en inomkatolsk dia$\log$. Men för honom hörde inte påvens ofelbarhet till dessa. Rahner menade, å sin sida, att läran om ofelbarhet ex cathedra möjliggör att även påvar och biskopar underkastas kyrkans lära och därmed förhindras ett slags teologisk godtycklighet. Katolicismen kan på detta sätt bli ett universum, ett eget tankesystem med vissa utfästa gränser.

Küng hade dock enligt Rahner rätt i att skriften är den normernas norm som inte är normerad (norma normans non normata), och därmed att Jesu ord är normerande i absolut mening för den kristnes liv och således även för kyrkans lära. Men Küng gjorde fel i att underminera en av betingelserna för den gemenskap som hävdar att Kristi ord är och bör vara normerande för såväl kyrkan som mänskligheten. Detta eftersom skriften inte kan begripliggöras utan den tradition som traderar, och således även förnyar, evangeliernas mening i nya sammanhang och epoker. Accepterar man inte detta, hävdade Rahner, är den inomkatolska dialogen bruten och man har undergrävt den gemenskap som så att säga kan göra Bibeln giltig som en trosregel.

Küngs svar var bedrövat. Han betonade att det var av Rahner som han lärde sig att förstå kyrkans dogmatik historiskt och han hävdade återigen att trosregeln inte behöver ofelbarhetsdogmen för att kunna konstituera en gemenskap. Kyrkans ofelbarhet fanns mer i förkunnelsen än i tolkningen av läran då bara Gud är ofelbar. Diskussionen pågick åtminstone till 1979, då troskongregationen fråntog Küng rätten att undervisa i fundamentalteologi vid universitetet i Tübingen. Det ledde till ännu mer ramaskri och protester världen över men han tilldelades snart en annan professur. Denna gång i ekumenisk teologi, vid samma universitet.

$\mathrm{Nu}$ påbörjades en ny period i Küngs liv då han ägnade sig åt dialog med världsreligionerna och skrev verk om islam och judendomen. Den ekumeniska ansatsen vidgades till en fråga om den mänskliga artens enhet. Men han fortsatte också att skriva verk i romersk-katolsk teologi samt populärvetenskapliga skrifter.

6. ”Jesus hätte davon nichts verstanden”, Der Spiegel 9/1972, II2. 
Av sina motståndare, och även forna vänner, beskrevs Küng allt oftare som en kändisteolog villig att byta ut seminarierummets seriösa diskussioner mot offentlighetens brist på nyans och förenklingar. Problemet var emellertid knappast att han försökte nå ut, eller ens försökte fă till stånd en skarp dialog om ödesfrågor inom kyrkan, utan att han blev indragen i den härlighetsindustri som så enkelt tunnar ut tänkandet och försvårar ambivalens och exakthet. Detta samtidigt som han själv predikade att sanningen finns i det perifera. I Betlehem snarare än i Rom. Denna vana gloria som inte minst den romersk-katolska traditionen varnar för påverkar rimligtvis synen på hans verk, vilket är olyckligt då flera av hans böcker håller hög klass. Medan andra, såsom exempelvis Ewiges Leben? från 1982, ${ }^{7}$ är av mer blandad kvalitet.

Det bör här betonas att även Küngs motståndare i efterhand understrukit hur hans kritik av kyrkan, som han själv menade att han var en lojal son till, bidrog till en nödvändig förnyelse. Hans förhoppning att påven skulle vara tjänare mer än monark är det nog få som i dag skulle ifrågasätta och kritiken av kyrkan som en communitas perfecta var han på inget sätt ensam om.

Den som vill veta mer om hans liv rekommenderas memoarerna i tre band och den personligt skrivna boken Was ich glaube, som salufördes som en slags sammanfattning av hans liv och teologi. ${ }^{8}$ Mest avtryck bland teologer tycks emellertid de tidigare ecklesiologiska verken ha gjort samt, förstås, boken om ofelbarhet.

Küngs publikationslista blev lång. Ett av hans mer filosofiska och kristologiska verk som förtjänar att uppmärksammas är den väldiga studien av Georg Wilhelm Friedrich Hegels (I770-I83I) kristologi, Menschwerdung Gottes. ${ }^{9}$ I den hävdar Küng att Hegel inte försökte kritisera den levande religionen utan den döda, avsomnade tron. För Hegel, skriver Küng, är det "de kristna [som] är argumentet mot kristendomen!" Och vad kan egentligen vara mer kristet än att erkänna den egna skulden och därmed anklaga sig själv och de egna? Frågan för såväl Küngs motståndare som forna vänner var dock om han var lika kritisk mot sina egna tankegångar som han var kritisk mot andras.

7. Hans Küng, Ewiges Leben?, Freiburg 1982.

8. Hans Küng, Erlebte Menschlichkeit, München 2013; Hans Küng, Was ich glaube, München 2009 .

9. Hans Küng, Menschwerdung Gottes: Eine Einführung in Hegels theologisches Denken als Prolegomena zu einer künftigen Christologie, Freiburg 1970. 